\title{
Evaluasi Geometri Peledakan Overburden Terhadap Digging Time Alat Gali PT Artamulia Tatapratama Jobsite Kuansing Inti Makmur Kabupaten Bungo, Provinsi Jambi
}

\author{
Rian $^{1 *}$, Yudhi Acnopha ${ }^{2}$, Juventa $^{1}$ \\ ${ }^{1}$ Program Studi Teknik Pertambangan Universitas Jambi, \\ 2 Program Studi Pertanian Universitas Jambi \\ Fakultas Sains dan Teknologi Universitas Jambi, Jl.Raya Jambi - Ma. Bulian, KM.15 Mendalo Indah, \\ Jambi,36361, Indonesia
}

\begin{abstract}
* Corresponding author: rianrizkyhp@gmail.com Received: May 7, 2021; Accepted: June 16, 2021. DOI: $10.31764 /$ jpl.v2i1.4683
\end{abstract}

\begin{abstract}
Abstrak. Tanjung Belit Project merupakan salah satu dari jobsite yang dikerjakan oleh PT Artamulia Tataparatama yang terletak di Desa Tanjung Belit, Kecamatan Jujuhan, Kabupaten Bungo, PT Kuansing Inti Makmur. Pembongkaran lapisan tanah penutup dilakukan dengan metode pemboran dan peledakan. Kondisi batubara jobsite ini merupakan batubara multi seam dengan overburden batupasir dan batulempung. Tingkat kekerasan batuan ini mengakibatkan adanya masalah dalam kegiatan free digging sehingga perlu dilakukannya kegiatan pemboran dan peledakan. Peledakan ini dimaksudkan untuk memberaikan batuan dari batuan induknya sehingga bidang lemahnya dapat terberai yang akan mempermudah untuk dilakukan penggalian. Rancangan geometri yang tidak optimal pada saat ini menghasilkan distribusi fragmentasi yang kurang baik yang menyebabkan terdapatnya sebagian daerah dekat lapisan batubara yang tidak terberai sempurna oleh lubang ledak, sehingga memperlambat digging time alat gali. Perbaikan geometri peledakan dimaksudkan untuk mengatasi masalah ini. Di mana burden sebesar $5 \mathrm{~m}$ dan spacing sebesar 6,5 m. Berdasarkan teori RL. Ash maka direkomendasikan dengan burden $5 \mathrm{~m}$ dan spacing sebesar $7 \mathrm{~m}$. Hasil perhitungan fragmentasi berdasarkan Kuz-Ram dari geometri yang diusulkan didapat fragmentasi yang kurang dari $130 \mathrm{~cm}$ sebanyak 70,64\% dari sebelumnya 63,68\% dengan kenaikan sebesar 6,96\%. Sedangkan fragmen ukuran lebih $130 \mathrm{~cm}$ (boulder) sebanyak 29,36\% dari sebelumnya sebesar 36,32\% dengan penurunan sebesar 6,66\%. Digging time geometri usulan diperoleh sebesar 8 detik dari sebelumnya 12 detik lebih cepat 4 detik. Produktivitas alat gali EX 1900 untuk material peledakan sebesar 1.146,54 BCM/jam dari awalnya sebesar 1.335,91 BCM/jam dengan kenaikan sebesar 190,37 BCM/jam.
\end{abstract}

Kata Kunci: gunakan Digging Time, Fragmentasi, Geometri, Produktivitas.

Abstract. Tanjung Belit Project is one of the jobsite carried out by PT Artamulia Tataparatama located in Tanjung Belit Village, Jujuhan District, Bungo Regency, with the owner PT Kuansing Inti Makmur. Demolition of overburden is done by drilling and blasting methods. The jobsite coal condition is a multi-seam coal with overburden sandstones and claystone. This level of rock hardness results in problems in free digging activities so drilling and blasting activities need to be carried out. This blasting is intended to provide rocks from its host rock so that the weak fields can be scattered which will make excavation easier. The geometric design that is not optimal at this time results in a poor distribution of fragmentation which causes the presence of a portion of the area near the coal seam which is not completely blown by explosive holes, thus slowing down the digging time of the digging tool. Refinement of blasting geometry is intended to overcome this problem. Where the burden of $5 \mathrm{~m}$ and spacing of $6,5 \mathrm{~m}$. Based on the RL theory. Ash then recommended a 5 $\mathrm{m}$ burden and 7 meters spacing. The results of the fragmentation calculation based on the proposed Kuz-Ram geometry obtained fragmentation of less than $130 \mathrm{~cm}$ as much as 70,64\% from the previous $63,68 \%$ with an increase of $6,96 \%$. While fragments measuring more than $130 \mathrm{~cm}$ (boulder) were $29,36 \%$ from the previous $36,32 \%$ with a decrease of 6,66\%. Digging time proposal geometry is obtained for 8 seconds from the previous 12 seconds 4 seconds faster. The productivity of the EX 1900 digger for blasting material is 1.146,54 $\mathrm{BCM} /$ hour from an initial amount of 1.335,91 BCM/hour with an increase of 190,37 BCM/hour.

Keywords: Digging Time, Fragmentation, Geometry, Production. 


\section{Pendahuluan}

Provinsi Jambi adalah daerah yang memiliki cadangan batubara. Berdasarkan data Badan Pusat Statistik Kabupaten Bungo tahun 2015, cadangan batubara di Bungo pada kecamatan Jujuhan adalah sebesar 113,55 juta ton dengan nilai kalori $5.300-6.500 \mathrm{Kcal} / \mathrm{Kg}$ (Suhada et al., 2009). PT Artamulia Tatapratama (ATP) merupakan salah satu kontraktor pertambangan yang turut berperan dalam mengeksploitasi batubara di daerah tersebut lebih tepatnya pada site Tanjung Belit, Kecamatan Jujuhan, Kabupaten Bungo, Provinsi Jambi.

Kegiatan penambangan PT ATP menggunakan metode tambang terbuka karena kondisi endapan batubara-nya terletak dekat permukaan dengan nilai SR yang masih ekonomis ditambang dengan metode tambang terbuka. Tambang terbuka adalah metode penambangan yang mana lokasi dan para pekerjanya serta alat berat yang digunakan berhubungan langsung dengan udara luar (States \& Mining, n.d.). Project Tanjung Belit yang dikerjakan PT ATP ini merupakan kontrak kerja sama dengan perusahaan PT Kuansing Inti Makmur (KIM) di mana wilayah Izin Usaha Pertambangan Operasi Produksi adalah milik PT KIM. PT ATP sebagai kontraktor pertambangan batubara beroperasi dengan metode open pit yang pengupasan overburden (OB) dilakukan secara berjenjang dengan salah satu komponen pendukungnya adalah aktivitas peledakan atau disebut blasting method.

Peledakan diperlukan bila kondisi pada front terdapat material overburden dengan parameter klasifikasi kemampugaruan (ripping chart) yang meliputi tingkat kekerasan tinggi, tingkat pelapukan yang rendah, serta pengaruh dari batas dan bidang diskontinuitas seperti jarak kekar, kemenerusan kekar, jarak pemisahan kekar dan orientasi kekar berpengaruh terhadap penggalian menggunakan alat gali Hitachi EX 1900 milik PT ATP dan pada kondisi tertentu dapat mengakibatkan bucket alat gali mengalami kerusakan akibat lapisan matrial batuan OB yang masif sebagaimana pada lokasi penelitian (Resources, 2008). Litologi batuan utama pit timur PT ATP tersusun berupa batupasir, konglomerat, batulempung, dan batubara.

Indikator yang menunjukkan keberhasilan dalam peledakan salah satunya adalah distribusi ukuran fragmen batuan hasil peledakan yang sesuai (Sasaoka et al., 2015). Pada proses loading, dapat dioptimalkan melalui waktu gali (digging time) alat gali. Oleh karena itu distribusi fragmen batuan hasil peledakan diupayakan harus memenuhi kriteria perusahaan sebesar kurang dari $130 \mathrm{~cm}$.

Perencanaan peledakan yang baik diawali dengan perancangan geometri peledakan yang tepat, sehingga dapat menghasilkan distribusi fragmentasi batuan yang seragam dan sesuai dengan plan (Sasaoka et al., 2015). Untuk itu dalam perencanaan peledakan harus memperhatikan dan menganalisa karakteristik batuan yang akan diledakkan, sehingga fragmen batuan yang dihasilkan tidak menurunkan digging time alat gali Hitachi EX 1900 yang mengakibatkan menurunnya atau bahkan tidak tercapainya target produktivitas OB harian. Dalam penelitian ini, akan dilakukan analisis terhadap geometri peledakan overbuden di PT Artamulia Tatapratama Bungo, Jambi, untuk melihat apakah hubungan fragmentasi batuan hasil peledakan terhadap digging time pada perusahaan efisien, jika belum maka penelitian ini diharapkan dapat memberikan solusi terhadap geometri peledakan untuk mempercepat digging timenya melalui fragmentasi batuan hasil peledakan nantinya.

\section{Metode Penelitian}

Penelitian ini dilakukan di PT Artamulia Tatapratam, Desa Tanjung Belit, Kecamatan Jujuhan, Kabupaten Bungo Provinsi Jambi. Data yang diambil dilapangan meliputi data primer dan didukung oleh data-data sekunder.

Data primer yang diperlukan antara lain: geometri peledakan yang meliputi burden, spacings stemming, panjang lubang, diameter lubang bor, subdrilling, tinggi jenjang, dan panjang isian bahan peledak. Kedua adalah data fragmentasi batuan hasil peledakan dengan pengambilan foto fragmentasi di setiap lokasi peledakan. Ketiga adalah digging time alat gali Hitachi EX 1900 terhadap material peledakan dengan cara pengukuran dengan menggunakan stopwatch, jenis material batuan, sifat fisik batuan berdasarkan parameter Lily.

Pada data sekunder dibutuhkan data sebagai berikut: gambar umum daerah penyelidikan yang meliputi peta lokasi perusahaan, peta situasi tambang, kondisi geologi setempat, data curah hujan. 
Kedua adalah informasi keadaan umum perusahaan yang meliputi spesifikasi alat pendukung peledakan, blasting report. Ketiga adalah data geoteknik berupa nilai densitas batuan. Dan yang keempat adalah spesifikasi alat gali. Data geometri peledakan aktual didapatkan dengan melakukan pengukuran langsung di lapangan dengan menggunakan meteran. Fragmentasi batuan overburden hasil peledakan aktual didapatkan dari foto menggunakan kamera ponsel yang selanjutnya akan dianalisis menggunakan software split dekstop 2.0. Sehingga diperoleh persentase distribusi fragmentasi batuan hasil peledakan. Untuk meningkatkan tingkat keyakinan dalam analisis fragmentasi maka dilakukan analisis fragmentasi menggunakan metode Kuz-Ram, sehingga didapat karakteristik ukuran fragmentasi dan persentasenya. Pengukuran digging time di lapangan diperlukan untuk analisis hubungan fragmentasi batuan terhadap digging time, di mana pengukuran nilai digging time diperoleh hasil pencatatan waktu cycle time. Dan akhirnya akan diperoleh produktivitas alat gali bcm per jamnya.

\section{Hasil dan Pembahasan}

\subsection{Karakteristik Massa dan Batuan}

\section{Sifat Fisika Batuan}

Sifat fisik yang diperlukan adalah bobot isi batuan yang akan diledakkan. Adapun jenis batuannya yang diperoleh dari Engineering Departement PT ATP berdasarkan kajian geoteknik telah dilakukan oleh konsultan LAPI ITB yang di kontrak oleh PT KIM, yakni batulempung (claystone) dan batupasir (sandstone). Harga bobot isi maksimal untuk batupasir dan batulempung sebagai overburden sebesar 2,4 ton $/ \mathrm{m}^{3}$.

\section{Faktor Pembobotan Batuan}

Peledakan berhubungan dengan suatu nilai yang disebut dengan Indeks Kemampuledakan (blastability index) yang berdasarkan faktor batuan (rock factor). Nilai dari blastability index dan rock factor dapat ditentukan dengan pembobotan beberapa parameter, yaitu Rock Mass description (RMD), Joint Plane Spacing (JPS), Joint Plane Orientation (JPO), Specific Grafity Influence (SGI) dan Hardness (H) (Brady \& Brown, 2006). Adapun hasil pembobotan ringkasannya adalah sebagai berikut:

Tabel 1. Pembobotan Blastablity Index.

\begin{tabular}{lcc}
\hline \multicolumn{1}{c}{ Parameter } & Kondisi di Lapangan & Pembobotan \\
\hline Rock Mass description (RMD) & Totally massive & 50 \\
Joint Plane Spacing (JPS) & Close (spasi < 0,1 m) & 10 \\
Joint Plane Orientation (JPO) & Dip Into Face & 20 \\
Specifik Grafity Influence (SGI) & 25 x SG - 50 & 10 \\
Hardness (H) & Skala Moh's batuan & 3 \\
\hline
\end{tabular}

(Sumber: Data Peneliti)

Tabel 1 tersebut merupakan hasil pengamatan di lapangan pada front area blasting pada umumnya. Diketahui bahwasanya overburden (OB) yang menutupi seam 300 upper merupakan seam paling atas dari pit timur. Batuan OB yang menutupi seam tersebut merupakan batupasir (sandstone) yang keras dengan sedikit bidang lemahnya dan dalam bentuk batuan yang sulit dilakukan free digging bahkan dapat menyebabkan bucket alat gali mengalami kerusakan akibat menggali material ini. Sama halnya dengan dominasi batulempung (claystone) atau lebih dikenal dengan blueclay karena warnanya relatif kebiruan. Batuan ini memiliki ketebalan yang besar dan kompak sehingga kedua batuan ini pembobotannya dikategorikan sebesar 50 .

Diketahui di lapangan batuan OB joint plane spacing kurang dari 0,1 m karena sedimentasi yang baik dan umur formasi yang tua dan minimnya aktivitas tektonik pada daerah penelitian ini, dengan demikian pembobotannya sebesar 10 atau close. Bidang perlapisan OB dapat diamati dengan arah perlapisan bidang ke arah dip in to face. Dengan demikian pembobotan orientasi bidangnya sebesar 20. Nilai pembototran Specifik Grafity Influence (SGI) yang diperoleh sebesar 10. Dan pembobotan blastability index yaitu kekerasan batuan, kekerasan batuan ini diuji dengan menggoreskan paku besi pada batuan, nilai pembobotannya sebesar 3 Moh's. 


\section{Geometri Aktual}

Data geometri aktual peledakan pada Tabel 2 menunjukkan bahwa, Burden aktual sebesar $5 \mathrm{~m}$ sudah aman untuk mencegah timbulnya fly rock yang dapat membahayakan kesemalamatan. Spacing aktual sebesar 6,5 m dinilai baik, namun masih bisa dioptimalkan dengan memperkecil untuk menurunkan jumlah boulder. Tinggi jenjang aktual sebesar $6 \mathrm{~m}$ sudah disesusaikan sebagaimana plan perusahaaan. Kedalaman lubang sebesar $6 \mathrm{~m}$ harus disesuaikan kembali terhadap tinggi jenjang sesar $6 \mathrm{~m}$, maka perlu ditambah kedalaman lubang melampai tinggi jenjang atau membuat subdrilling untuk menghindari terbentuknya toe pada front. Stemming sebesar 3,57 m, disesuaikan dengan burden dan stemming ratio untuk mengoptimalkan distribusi energi peledakan. Airdeck sebesar $1 \mathrm{~m}$ telah tepat, apabila lebih dari $1 \mathrm{~m}$ maka dapat menurunkan energi peledakannya, sebab jumlah bahan peledak berkurang ataupun dengan mengurangi panjang stemming dapat menyebabkan materal tidak terberai dengan optimal karena energi peledakan tidak menyebar ke bidang batuan tetapi hanyak lepas ke udara bebas (Nikzad et al., 2018). Panjang isian aktual sebesar 1,26 m, panjang isian tersebut pendek karena mengikuti jumlah isian bahan peledak yang sedikit terhadap variabel terikat yaitu diameter lubang ledak sebesar $0,15875 \mathrm{~m}$. Volume batuan hanya sebesar $195 \mathrm{BCM}$, maka perlu dievaluasi geometri burden, spacing dan kedalaman lubang guna menurunkan persentase bongkahan. Isian bahan peledak aktual sebesar $20 \mathrm{~kg} / \mathrm{lubang}$, maka untuk menghasilkan valume material yang diberai maka perlu ditingkatkan menyesuaikan dengan gemetri dan aspek keselamatan serta lingkungan. Powder Factor (PF) aktual sebesar 0,10 kg/BCM, semakin besar jumlah bahan peledakan maka akan semakin besar nilai $\mathrm{PF}$ dan persentase bongkah akan semakin sedikit.

Tabel 2. Geometri aktual

\begin{tabular}{clc}
\hline No & \multicolumn{1}{c}{ Parameter } & Geometri Aktual Peledakan \\
\hline 1 & Burden $(\mathrm{m})$ & 5 \\
2 & Spacing $(\mathrm{m})$ & 6,5 \\
3 & Stemming $(\mathrm{m})$ & 3,57 \\
4 & Subdrilling $(\mathrm{m})$ & 0 \\
5 & Kedalaman Lubang $(\mathrm{m})$ & 6 \\
6 & Panjang Kolom Isian $(\mathrm{m})$ & 1,26 \\
7 & Jumlah Isian $(\mathrm{kg})$ & 20 \\
8 & Powder Factor $(\mathrm{kg} / \mathrm{bcm})$ & 0,10 \\
\hline
\end{tabular}

\section{Perhitungan Ketercapaian Target Produksi Aktual}

Target produksi overburden inventory yang ditargetkan oleh perusahaan adalah sebesar 22.011.322 ton dalam semester 2 tahun 2018. Sedangkan material blasting sebesar 25\% dari overburden inventory. Produksi OB dalam per tahun sebesar 5.502.833 BCM/tahun. OB dalam per bulan sebesar 458.569,42 BCM/bulan. Sehingga produksi OB per hari sebesar 15.285,65 BCM/hari. Bila menggunakan geometri plan perusahaan dengan burden $5 \mathrm{~m}$, spacing $6,5 \mathrm{~m}$ dan kedalaman lubang $6 \mathrm{~m}$. Maka jumlah lubang ledak yang diperlukan sebanyak 78 lubang/hari.

\subsection{Evaluasi Fragmentasi Hasil Peledakan Overburden}

\section{Metode Split Dekstop}

Berdasarkan data prediksi fragmentasi menurut Kuz-Ram, data tersebut dilakukan evaluasi secara aktual dengan tujuan menilai kebenaran data prediksi distribusi ukuran fragmentasi Kuz-Ram tersebut apakah telah sesuai dengan keadaan aktual di lapangan pasca dilaksanakannya peledakan. Evaluasi aktual ini menggunakan software Split Dekstop 2.0. Program ini melakukan perhitungan distribusi fragmentasi dari batuan melalui analisis gambar digital dengan menempatkan skala pembanding yaitu berupa sebuah bola karet dengan diameter $18 \mathrm{~cm}$ (Gambar 1). Dari hasil evaluasi distribusi fragmentasi hasil peledakan menggunakan software ini dengan import foto yang telah disimpan di komputer dan telah dilakukan sebagaimana prosedur pengerjaan, maka diperoleh hasil pada tabel 3 berikut ini. 
Tabel 3. Data Fragmentasi di Pit Timur Split Dekstop

\begin{tabular}{|c|c|c|c|c|c|c|}
\hline No & Tanggal & Pit & $\overline{\mathbf{X}}$ & Xc & $\begin{array}{l}\text { Tertahan }(\mathrm{R}) \\
\geq 130 \mathrm{~cm}\end{array}$ & $\begin{array}{c}\operatorname{Lolos}(Y) \\
\geq 130 \mathrm{~cm}\end{array}$ \\
\hline 1 & $23 / 6 / 2018$ & Timur & 52,16 & 113,73 & 0 & 100 \\
\hline 2 & $23 / 6 / 2018$ & Timur & 43,77 & 153,52 & 0 & 100 \\
\hline 3 & $24 / 6 / 2018$ & Timur & 47,41 & 95,11 & 0 & 100 \\
\hline 4 & $24 / 6 / 2018$ & Timur & 53,10 & 127,63 & 0 & 100 \\
\hline 5 & $08 / 7 / 2018$ & Timur & 16,50 & 50,68 & 0 & 100 \\
\hline 6 & $09 / 7 / 2018$ & Timur & 44,28 & 118,78 & 0 & 100 \\
\hline \multirow[t]{2}{*}{7} & $11 / 7 / 2018$ & Timur & 21,19 & 57,71 & 0 & 100 \\
\hline & Rata-rata & & 39,77 & 102,45 & $\mathbf{0}$ & 100 \\
\hline
\end{tabular}

$\mathrm{X}_{\mathrm{c}}=$ ukuran terbesar $(\mathrm{cm}) ; \bar{X}=$ Ukuran fragmen rata-rata $(\mathrm{cm}) ; \mathrm{R}=$ Persen material yang tertahan pada ayakan ukuran $130 \mathrm{~cm}(\%) ; \mathrm{Y}=$ Persen material (percent passing) lolos dari ayakan ukuran $130 \mathrm{~cm}$ (\%). (Sumber: Data Peneliti).

Data pada Tabel 3 menunjukkan ukuran fragmentasi rata-rata sebesar 39,77 cm dan ukuran terbesar mencapai $102,45 \mathrm{~cm}$. Sedangkan nilai distribusi rata-rata $(\mathrm{R})$ persen material yang tertahan pada ayakan ukuran $130 \mathrm{~cm}$ yaitu $0 \%$ dan rata-rata $(\mathrm{Y})$ persen material yang lolos pada ayakan ukuran $130 \mathrm{~cm}$ yaitu $100 \%$. Ukuran distribusi fragmentasi ini masih belum dapat mewakili keseluruhan data fragmen sebab material mengalami pemberaian di bagian lapisan bagian dalam.

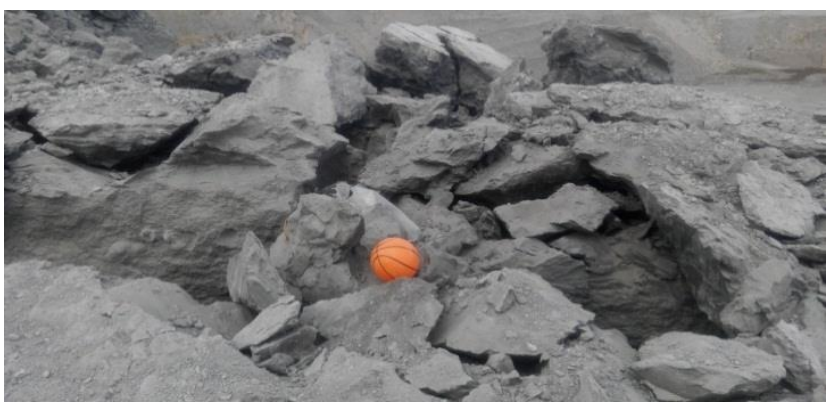

Gambar 1. Fragmentasi Hasil Peledakan

\section{Metode Kuz-Ram}

Berdasarkan data geometri peledakan di pit timur pada tabel sebelumnya maka didapatkan nilai rata-rata dari geometri peledakan. Dari geometri peledakan tersebut dapat diketahui bahwa di pit timur PT Artamulia Tatapratama menggunakan rata-rata burden $5 \mathrm{~m}$, spacing 6,5 m, kedalaman lubang $5,86 \mathrm{~m}$, stemming $3,57 \mathrm{~m}$ dan panjang isian PC $1,25 \mathrm{~m}$. Sangat penting mengetahui fragmentasi hasil peledakan secara teoritis sebelum peledakan dilakukan dengan mempertimbangkan faktor geologi dan parameter peledakan lainnya.

Dari data geometri dapat dapat dihitung distribusi dari fragmentasi hasil peledakan pada tiap-tiap data geometri tersebut dang menggunakan metode Kuz-Ram. Metode Kuz-Ram merupakan suatu metode untuk memprediksi fragmentasi hasil peledakan yang terdiri dari gabungan persamaan Kuznetsov dan Cunningham yang memberikan ukuran fragmentasi batuan ukuran fragmentasi batuan rata-rata, sedangkan persamaan Rossin-Rammler menentukan persentase material yang tertampung diayakan dengan ukuran tertentu. Dengan menggunakan persamaan-persamaa tersebut dapat diketahui distribusi ukuran fragmen dan persentase material yang lolos pada ayakan tertentu (Jethro et al., 2018).

Berdasarkan pada data Tabel 4, diketahui bahwa nilai distribusi ukuran fragmentasi rata-rata batuan hasil peledakan yaitu $\bar{X}=61,86 \mathrm{~cm}$ dengan nilai indeks keseragaman (n) yaitu 0,47 . Nilai (n) mengindikasikan tingkat keseragaman distribusi ukuran fragmentasi hasil peledakan. Untuk range nilai (n) umumnya bernilai antara 0,36 sampai 0,52 dan semakin besar nilai (n) maka distribusi ukuran fragmentasi tersebut semakin seragam dalam suatu peledakan. Pada data fragmentasi di pit timur metode Kuz-Ram di atas terdapat sebanyak $36,32 \%$ material yang tertahan sedangkan sisanya $63,68 \%$ material tersebut lolos pada ayakan ukuran $\geq 130 \mathrm{~cm}$. Sehingga dapat diasumsikan bahwa ada sebanyak $36,32 \%$ material hasil peledakan yang berukuran lebih dari $130 \mathrm{~cm}$ dari keseluruhan hasil peledakan dikarenakan tertahan dan tidak lolos dari ukuran ayakan $130 \mathrm{~cm}$. 


\begin{tabular}{|c|c|c|c|c|c|c|c|c|}
\hline No & Tanggal & Pit & $\begin{array}{l}\text { Jumlah } \\
\text { Lubang }\end{array}$ & $\begin{array}{l}(\overline{\boldsymbol{X}}) \\
(\mathbf{c m})\end{array}$ & $\mathbf{n}$ & $\begin{array}{c}\mathrm{Xc} \\
(\mathbf{c m})\end{array}$ & $\begin{array}{c}\text { Tertahan } \\
(\text { R) }(\%) \\
\geq 130 \mathrm{~cm}\end{array}$ & $\begin{array}{c}\text { Lolos } \\
(Y)(\%) \\
\geq 130 \mathrm{~cm}\end{array}$ \\
\hline 1 & $23 / 6 / 2018$ & Timur & 27 & 65 & 0,47 & 142,60 & 37,10 & 62,90 \\
\hline 2 & $23 / 6 / 2018$ & Timur & 50 & 64 & 0.47 & 139,46 & 36,72 & 63,28 \\
\hline 3 & $24 / 6 / 2018$ & Timur & 20 & 63 & 0,47 & 138,42 & 36,59 & 63,41 \\
\hline 4 & $24 / 6 / 2018$ & Timur & 50 & 64 & 0,47 & 140,24 & 36,82 & 63,18 \\
\hline 5 & 08/7/2018 & Timur & 44 & 59 & 0,52 & 121,08 & 34,04 & 65,96 \\
\hline 6 & 09/7/2018 & Timur & 50 & 58 & 0,50 & 119,55 & 33,87 & 66,13 \\
\hline \multirow[t]{2}{*}{7} & $11 / 7 / 2018$ & Timur & 36 & 60 & 0,36 & 166,73 & 39,11 & 60,89 \\
\hline & Rata-rata & & 40 & 61,86 & 0,47 & 138,30 & 36,32 & 63,68 \\
\hline
\end{tabular}

$\mathrm{X}_{\mathrm{c}}=$ ukuran terbesar $(\mathrm{cm}) ; \bar{X}=$ Ukuran fragmen rata-rata $(\mathrm{cm}) ; \mathrm{R}=$ Persen material yang tertahan pada ayakan ukuran $130 \mathrm{~cm}(\%)$; Y = Persen material (percent passing) lolos dari ayakan ukuran $130 \mathrm{~cm}$ (\%). (Sumber: Data Peneliti).

Tabel 5. Perbandingan Fragmentasi Teoritis (Kuz-Ram) dan Split Dekstop

\begin{tabular}{cccccc}
\hline Kategori & cm & Teori & Split Dekstop & Selisih & $\begin{array}{c}\text { Standar } \\
\text { Devisiasi }\end{array}$ \\
\hline Oversize & $>130$ & $35,92 \%$ & $0 \%$ & $35,92 \%$ & 25,40 \\
Target size & $0-130$ & $64,08 \%$ & $100 \%$ & $35,92 \%$ & 70,71 \\
\hline
\end{tabular}

(Sumber: Data Peneliti)

Berdasarkan komparasi antara data estimasi fragmen dengan menggunakan metode Kuz-Ram dan split dekstop, diketahui distribusi fragmen oversize pada Kuz-Ram sebesar 35,92\% sedangkan split dekstop sebesar $0 \%$ dengan selisih relatif 35,92\%. Pada ukuran target size distribusi fragmen metode Kuz-Ram sebesar 64,08\% sedangkan hasil split dektop sebesar 100\% dengan selisih relatif 35,92\%.

\section{Analisis Regresi Polynomial}

Berdasarkan gambar 2 hubungan antara powder factor dan persentase material oversize yang dianalisis dengan menggunakan regresi polinominal di mana persentase fragmentasi batuan kategori oversize sebagai variabel y dan powder factor sebagai variabel $\mathrm{x}$, yang mana besar powder factor yang digunakan mempengaruhi tingkat persentase fragmentasi batuan kategori oversize dengan nilai koefisien determinasi sebesar 78,17\% dengan tingkat error sebesar 22,83\% yang dipengaruhi oleh faktor lain. Gambar 2 menunjukkan semakin sedikit isian bahan peledak persentase boulder hasil peledakan semakin banyak. Pendekatan hubungan polinomial di mana persentase material boulder sebagai variabel y dan isian bahan peledak sebagai variabel $\mathrm{x}$ menunjukkan bahwa isian bahan peledak berkorelasi negatif terhadap persentase boulder dengan koefisien 0,7817. Berdasarkan pengolahan dan analisa data terhadap perbandingan antara powder factor dengan persentase material boulder (\%) menggunakan metode regresi polynomial ordo 2, maka diperoleh persamaan

$$
y=15290 x^{2}-3533,7 x+237,74
$$

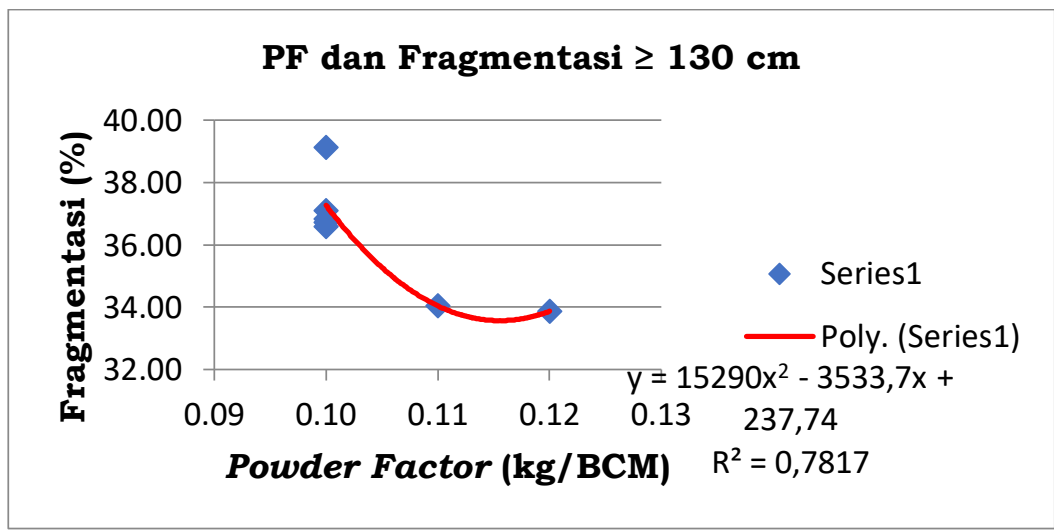

Gambar 2. PF dan Fragmentasi Batuan - Category Oversize $>130 \mathrm{~cm}$. 


\section{Digging Time Alat Gali Aktual}

Pengamatan digging time merupakan salah satu parameter untuk memberikan penilaian terhadap kinerja alat gali muat terhadap ukuran fragmen hasil peledakan. Digging time merupakan waktu penggalian alat gali muat yang dihitung ketika bucket menancap pada fragmen hasil peledakan kemudian bergerak menggali dan mengangkut sampai posisi lepas dari batuan yang digali. Selama pengamatan berlangsung alat gali muat yang bekerja adalah Hitachi EX 1900 dengan nomor seri EX200-001 dengan kapasitas $12 \mathrm{~m}^{3}$. Digging time yang dihasilkan oleh alat gali muat saat menggali fragmen hasil peledakan dapat dilihat pada Tabel 7.

Tabel 7. Digging Time Alat Gali Muat Hitachi EX-1900

\begin{tabular}{cccc}
\hline \multirow{2}{*}{ No } & Tanggal & \multicolumn{2}{c}{ Blasting } \\
\cline { 3 - 4 } & & Jumlah digging & Digging Time (detik) \\
\hline 1 & 23 Juni & 545 & 13 \\
2 & 23 Juni & 537 & 12 \\
3 & 24 Juni & 521 & 12 \\
4 & 24 Juni & 530 & 12 \\
5 & 8 Juli & 502 & 11 \\
6 & 9 Juli & 513 & 10 \\
7 & 11 Juli & 510 & 13 \\
Rata-rata & & & $\mathbf{1 2}$ \\
\hline
\end{tabular}

(Sumber: Data Peneliti)

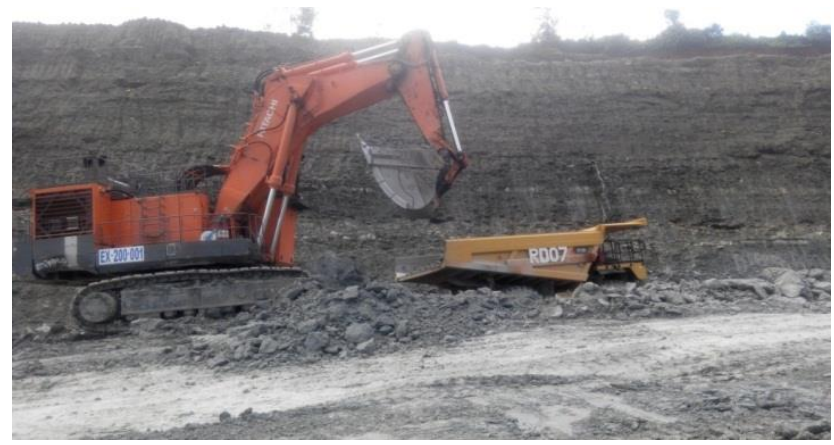

Gambar 3. Proses Digging Time Alat Gali Muat EX-1900 (Sumber: Dokumentasi Peneliti).

\section{Hubungan Fragmentasi Batuan terhadap Digging Time}

Tabel 7 menunjukkan hubungan linear antara jumlah digging terhadap digging time-nya, hal ini dipengaruhi oleh tingkat kemudahan penggalian material sehingga semakin mudah material untuk digali maka waktu penggalian akan lebih cepat dan intensitas digging akan lebih banyak dalam satu rit. Oleh karena itu, besar atau kecilnya waktu gali dipengaruhi oleh kemudahan dalam penggalian material. Tabel 8 menyajikan hubungan fragmentasi dan digging time.

Berdasarkan hasil pengambilan data digging time di lapangan dengan menggunakan stopwatch didapatkan digging time aktual batuan hasil peledakan pada seluruh lokasi. Untuk digging time ratarata setiap lokasi 12 detik di atas standar yang ditetapkan perusahaan yaitu 9 detik.

Digging time dihitung pada saat bucket menyentuh tanah samapi terisi penuh dan mulai terangkat. Digging time berpengaruh terhadap ketercapaian produksi serta dapat dijadikan salah satu parameter untuk mengetahui apakah proses peledakan tersebut berhasil atau tidak. Peledakan yang baik akan menghasilkan digging time yang kecil atau cepat. Digging time akan mempengaruhi produktivitas alat gali Hitachi EX-1900. Dalam hal ini dibahas hubungan fragmentasi oversize dengan digging time alat gali yang dihasilkan. Dari hubungan tersebut diharapkan dapat dilihat tingkat keakurasian 
antara fragmentasi oversize dengan digging time. Hubungan fragmentasi oversize dengan digging time dapat dilihat pada Gambar 4.

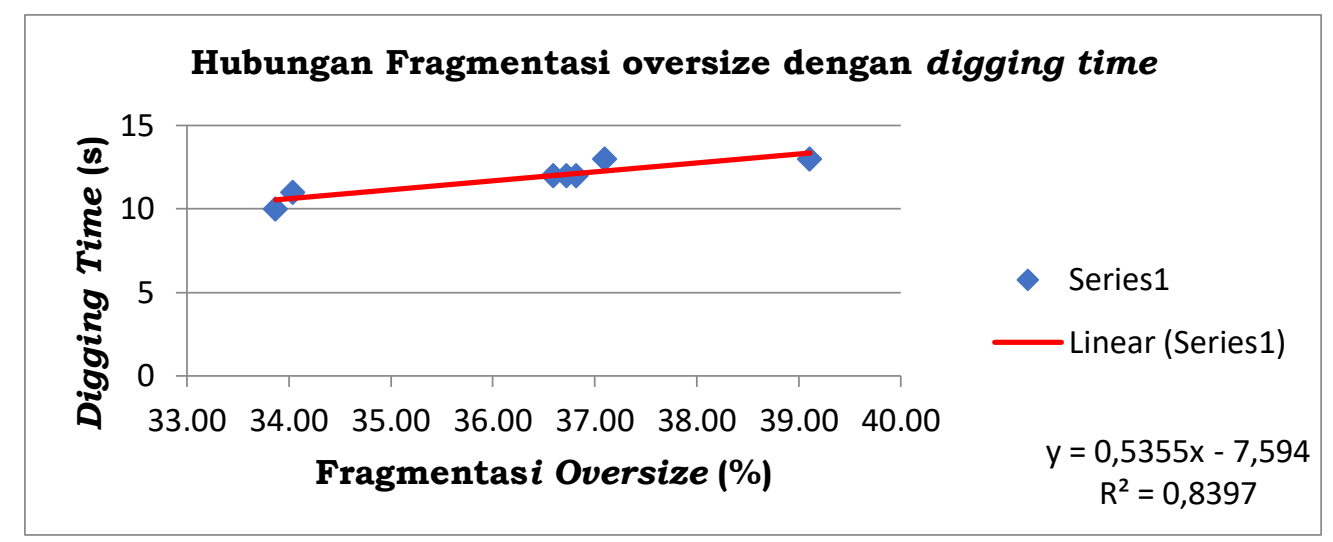

Gambar 4. Hubungan Fragmentasi oversize terhadap Digging Time

Tabel 8. Fragmentasi Aktual Peledakan terhadap Digging Time

\begin{tabular}{lccc}
\hline \multirow{2}{*}{ No. } & Tanggal & Fragmentasi $\mathbf{~ K u z - R a m}$ & Digging Time Rata-rata \\
\cline { 3 - 4 } & & $(>\mathbf{1 3 0} \mathbf{~ c m})(\boldsymbol{\%})$ & Detik \\
\hline 1 & 23 Juni & 37,10 & 13 \\
2 & 23 Juni & 36,72 & 12 \\
3 & 24 Juni & 36,59 & 12 \\
4 & 24 Juni & 36,82 & 12 \\
5 & 8 Juli & 34,04 & 11 \\
6 & 9 Juli & 33,87 & 10 \\
7 & 11 Juli & 39,11 & 13 \\
& Rata-rata & $\mathbf{3 6 , 3 2}$ & $\mathbf{1 2}$ \\
\hline
\end{tabular}

(Sumber: Data Peneliti)

Berdasarkan gambar 4 terlihat bahwa hubungan anatara fragmentasi oversize terhadap besarnya nilai digging time berbanding lurus, dapat diartikan jika persentase fragmentasi oversize meningkat maka besarnya nilai digging time juga ikut meningkat. Dilihat dari grafik fungsi menunjukan pergerakan nilai cenderung meningkat, hal ini disebabkan kemudahan alat gali bergerak, adanya bongkahan-bongkahan dan retakan-retakan yang dihasilkan dari kegiatan peledakan, hal ini menyebabkan semakin lama waktu yang dibutuhkan alat gali dalam melakukan kegiatan gali muat, dengan tingkat keakurasian $83,97 \%$. Hasil pengamatan persentase fragmentasi oversize metode KuzRam, selanjutnya dilakukan percobaan dengan menurunkan persentase fragmentasi oversize-nya. Untuk digging time hasil percobaan diprediksi menggunakan metode regresi liner yang sudah diperoleh sebelumnya dari fragmentasi oversize aktual, sehingga diperoleh prediksi digging time fragmentasi rata-rata aktual yaitu 12 detik.

\subsection{Rancangan Geometri Peledakan}

Geometri peledakan sangat berpengaruh terhadap fragmentasi hasil kegiatan peledakan. Geometri kedalaman lubang, spacing dan jumlah bahan peledak yang tidak ideal dapat menurunkan keoptimalan hasil peledakan terutama pada fragmentasi material peledakan. Sifat fisik dan mekanik batuan serta struktur geologi pada area yang akan diledakan. Penentuan geometri peledakan mulai dari burden, spacing, panjang kolom isian, stemming, tinggi jenjang, subdrilling, dan kedalaman lubang ledak harus memperhatikan karakteristik massa batuan dan kondisi geologi setempat agar memperoleh fragmentasi yang diharapkan. Ukuran burden dan spacing saat ini yaitu $5 \mathrm{~m}$ dan $6,5 \mathrm{~m}$ dilokasi penelitian belum dikatakan baik karena rambatan gelombang detonasi yang dihasilkan dari lubang ledak sampai dikembalikannya energi berupa energi tensile menjadi lama dan membuat asosiasi antar gelombang menjadi tidak maksimal. 
Terdapatnya bidang bebas pada kegiatan peledakan juga akan mempengaruhi hasilnya. Karena fungsi dari bidang bebas adalah sebagai pengantar energi pada lubang ledak. Ukuran stemming juga memiliki peranan penting dalam menjaga distribusi energi peledakan tetap seimbang antara daerah yang terisi bahan peledak dan daerah yang tidak terisi bahan peledak. Jika stemming terlalu pendek maka pada saat peledakan lubang akan terbongkar terlalu cepat karena tidak termampatkan dengan baik maka gas yang dihasilkan oleh bahan peledak yang meledak di dalam lubang ledak akan keluar dan tekanannya akan berkurang (loose energy) sehingga tidak cukup kuat untuk membuat rekahan dan memecah batuan. Akibat terjadinya loose energy ini adalah fragmentasi yang dihasilkan berukuran besar. Pada daerah penelitian digunakan drilling cutting sebagai stemming untuk mengunci gas peledakan di dalam lubang ledak. Material drill cutting ini cukup baik untuk digunakan sebagai stemming di lokasi peledakan pada lubang kering akan tetapi pada lubang basah material ini kurang efektif karena material drill cutting memiliki kelembaman yang rendah terhadap air.

Setelah dilakukan perhitungan dan analisis data, disimpulkan bahwa perlu dilakukan redesign atau pembuatan rencana geometri peledakan yang baru. Dalam hal ini peneliti menggunakan satu persamaan untuk menentukan geometri peledakan usulan yaitu R.L Ash (Ash, 1985), di mana selanjutnya jumlah isian bahan peledak dari geometri tersebut dikorelasikan dengan teori Scale Distance guna memprediksi getaran yang akan ditimbulkan dari jumlah isian bahan peledakan pada geometri peledakan dengan maksud untuk mendapatkan fragmentasi yang baik dengan mempertimbangkan keselamatan dan lingkungan. Berikut hasil rancangan geometri peledakan usulan (Tabel 9).

Tabel 9. Geometri Peledakan Usulan Menurut R. L. Ash (1985)

\begin{tabular}{clcc}
\hline No. & \multicolumn{1}{c}{ Parameter } & Geometri Usulan & Satuan \\
\hline 1 & Burden & 5 & Meter \\
2 & Spacing & 7 & Meter \\
3 & Stemming & 4,25 & Meter \\
4 & Subdrilling & 1 & Meter \\
5 & Panjang Kolom Isian & 1,77 & Meter \\
6 & Air deck & 1 & Meter \\
7 & Kedalaman Lubang ledak & 7 & Meter \\
8 & Tinggi Jenjang & 6 & Meter \\
9 & Jumlah ANFO & 28 & Kg \\
10 & Volume Batuan Diledakkan & 245 & BCM \\
11 & Powder Factor & 0,11 & $\mathrm{Kg} / \mathrm{BCM}$ \\
\hline
\end{tabular}

(Sumber: Data Peneliti)

Burden sebesar $5 \mathrm{~m}$ diperoleh dari karaketriktik ANFO berupa: berat jenis, kecepatan ledak dan kerapatan batuan sehingga diperoleh nilai Burden Ratio (BR). BR ini digunakan sebagai pengali explosive diamater. Spacing sebesar $7 \mathrm{~m}$ diperoleh dari panjang burden dikalikan dengan normal delay criteria. Tinggi jenjang sebesar $6 \mathrm{~m}$ sudah susuai merujuk pada rekomendasi geoteknik perusahaan. Kedalaman lubang sebesar $7 \mathrm{~m}$. Subdrilling sebesar $1 \mathrm{~m}$ diperoleh dari kedalaman lubang dikurangi dengan tinggi jenjang rekomendasi. Stemming sebesar 4,25 m diperoleh dari burden dikali dengan stemming ratio $(0,7-1,3)$. Di mana ratio ini untuk menentukan tingkat air blast dan stress balance control. Airdeck sebesar $1 \mathrm{~m}$ telah ideal. Panjang isian sebesar 1,77 $\mathrm{m}$ diperoleh dari kedalaman lubang dikurangi stemming dan air deck. Volume batuan sebesar $245 \mathrm{BCM}$ diperoleh dari burden dikali spacing dan kedalaman lubang. Isian bahan peledak sebesar $28 \mathrm{~kg} / \mathrm{lubang}$ diperoleh dari panjang isian bahan peledak dikali loading density. Powder Factor (PF) sebesar 0,11 kg/BCM diperoleh berat bahan bahan peledak dibagi volume batuan. Batuan tertahan pada ayakan $(\geq 130 \mathrm{~cm})$ sebesar $29,36 \%$ terjadi penurunan fragmen karena nilai PF yang meningkat. Batuan lolos pada ayakan $(\geq 130 \mathrm{~cm})$ sebesar $70,64 \%$ nilai ini merupakan nilai pengurangan batuan yang tertahan $29,36 \%$ dari $100 \%$ keseluruhan batuan yang diledakkan. Digging time sebesar 8 detik. Nilai digging time ini dipengaruhi oleh jumlah fragmentasi $\geq 130 \mathrm{~cm}$ menurun menjadi $29,36 \%$. 
Target produksi overburden inventory yang diinginkan oleh perusahaan adalah sebesar 22.011.322 ton dalam semester 2 tahun 2018, sedangkan material blasting sebesar 25\% dari overburden inventory. Produksi OB dalam per tahun sebesar 5.502.833 BCM/tahun. OB dalam per bulan sebesar 458.569,42 BCM/bulan. Sehingga produksi OB per hari sebesar 15.285,65 BCM/hari. Bila menggunakan geometri usulan perusahaan dengan burden $5 \mathrm{~m}$, spasi $5,5 \mathrm{~m}$ dan kedalaman lubang 6,08 m. Maka jumlah lubang ledak yang diperlukan sebanyak 63 lubang/hari.

Tabel 10. Perbandingan Hasil dari Data Geometri Aktual dan Usulan

\begin{tabular}{|c|c|c|c|}
\hline \multirow{2}{*}{ No } & \multirow{2}{*}{ Parameter } & \multicolumn{2}{|c|}{ Geometri Peledakan } \\
\hline & & Aktual & Usulan \\
\hline 1 & Burden (m) & 5 & 5 \\
\hline 2 & Spacing $(\mathrm{m})$ & 6,5 & 7 \\
\hline 3 & Stemming (m) & 3,57 & 4,25 \\
\hline 4 & Subdrilling $(\mathrm{m})$ & 0 & 1 \\
\hline 5 & Kedalaman Lubang (m) & 6 & 7 \\
\hline 6 & Panjang Kolom Isian (m) & 1,25 & 1,77 \\
\hline 7 & Jumlah Isian (kg) & 20 & 28 \\
\hline 8 & Powder Factor (kg/bcm) & 0,10 & 0,11 \\
\hline \multicolumn{4}{|c|}{ Perhitungan Fragmentasi Peledakan Berukuran Boulder (\%) } \\
\hline \multirow[t]{3}{*}{1} & Kuz-Ram & & \\
\hline & Fragmentasi Rata-Rata $(\overline{\mathbf{X}})(\mathrm{cm})$ & 61,86 & 61 \\
\hline & Persentase Oversize (\%) & 36,32 & 29,36 \\
\hline \multirow[t]{4}{*}{2} & Split Dekstop & & \\
\hline & $\begin{array}{l}\text { Fragmentasi Rata-Rata }(\overline{\mathbf{X}}) \\
(\mathrm{cm})\end{array}$ & 39,77 & - \\
\hline & Persentase Oversize (\%) & 0 & - \\
\hline & \multicolumn{3}{|c|}{ Perhitungan Produktivitas Alat Gali Pada Front Peledakan (bcm/jam) } \\
\hline 1 & Digging Time (detik) & 12 & 8 \\
\hline 2 & Cycle Time (detik) & 28 & 24 \\
\hline 3 & Digging Rate (bcm/jam) & $1.157,14$ & 1.350 \\
\hline
\end{tabular}

Dalam rekomendasi ini, peneliti menggunakan perhitungan dengan peningkatan nilai powder factor (PF), sehingga didapat nilai burden dan spacing yang seharusnya. Teori R.L Ash dijadikan sebagai patokan dan dasar dalam menjalankan kegiatan peledakan di PT ATP, sehingga peneliti merekomendasikan geometri peledakan secara teoritis menurut RL. Ash namun dengan kriteria kajian geometri yang berbeda. Perhitungan dengan menggunakan pendekatan ini berdasarkan pada powder factor $(\mathrm{PF})$ yang diinginkan, loading density (de) dan tinggi jenjang $(\mathrm{H})$ yang disesuaikan dengan kondisi di lapangan. Kemudian dari data di atas dapat diketahui persentase fragmentasi boulder aktual sebesar 36,32\% mengalami penurunan menjadi $29,36 \%$, dengan digging time awal 12 detik menjadi 8 detik, dibawah 1 detik dari target perusahaan yaitu 9 detik. Sehingga produktivitas per jam dari $1.157,14 \mathrm{bcm} / \mathrm{jam}$ naik menjadi $1.350 \mathrm{bcm} / \mathrm{jam}$. Dengan ketentual pengurangan panjang spacing menjadi $7 \mathrm{~m}$ dan isian bahan peledaknyanya ditingkatkan menjadi $28 \mathrm{~kg} / \mathrm{lubang}$

\section{Kesimpulan}

Kesimpulan dari hasil penelitian ini sebagai berikut:

1. Geometri yang diterapkan PT Artamulia Tatapratama adalah: diameter lubang 6,25 inch, pola pemboran zig-zag, burden $5 \mathrm{~m}$, spacing $6,5 \mathrm{~m}$, kedalaman lubang $6 \mathrm{~m}$, stemming $3,57 \mathrm{~m}$, airdeck $1 \mathrm{~m}$ dan panjang isian PC yaitu $1,26 \mathrm{~m}$. 
2. Distribusi fragmen batuan hasil perhitungan model Kuz-Ram adalah $61,86 \mathrm{~cm}$ untuk rata-rata ukuran fragmen batuan, $36,32 \%$ untuk selang ukuran fragmen batuan $\geq 130 \mathrm{~cm}$, dan $63,68 \%$ untuk selang ukuran fragmen batuan $\leq 130 \mathrm{~cm}$.

3. Digging time aktual rata-rata di Pit timur oleh alat gali Hitachi EX 1900 adalah 12 detik terhadap material blasting dengan batuan sandstone dan claystone, dengan digging rate sebesar 1.146,54 $\mathrm{BCM} / \mathrm{jam}$.

4. Rancangan geometri peledakan yang diusulkan untuk PT Artamulia Tatapratama adalah sebagai berikut: burden $5 \mathrm{~m}$, spacing $7 \mathrm{~m}$, kedalaman lubang $7 \mathrm{~m}$, stemming $4,25 \mathrm{~m}$, airdeck $1 \mathrm{~m}$ dan panjang isian PC yaitu $1,77 \mathrm{~m}$, dengan prediksi fragmen adalah: $61 \mathrm{~cm}$ untuk rata-rata ukuran fragmen batuan, $29,36 \%$ untuk selang ukuran fragmen batuan $\geq 130 \mathrm{~cm}, 70,64 \%$ untuk selang ukuran fragmen batuan $\leq 130 \mathrm{~cm}, 8$ detik untuk prediksi digging time alat gali Hitachi EX 1900 dengan digging rate sebesar 1.335,91 $\mathrm{BCM} / \mathrm{jam}$.

\section{Referensi}

Ash, R. L. (1985). Flexural rupture as a rock breakage mechanism in blasting. Fragmentation by Blasting, Ed. W. Forney, R. Boade and L. Costin, Soc. for Exp. Mechanics, 24-29.

Batanghari, T. D. A. N., Jambi, P., Suhada, D. I., Triono, U., \& Rizki, M. R. (2009). No Title.

Brady, B. H. G., \& Brown, E. (2006). Rock Mechanics For Underground Mining. Chapman and Hall, 1993.

Jethro, M., David, O., \& Peter, A. (2018). Rock Fragmentation Prediction using Kuz-Ram Model.

Nikzad, M., Asadi, A., Yasrebi, A., Wetherelt, A., \& Afzal, P. (2018). Blast fragmentation classification using number-size (N-S) fractal model in Jalal-abad iron mine. Archives of Mining Sciences, 63, 783-796. https://doi.org/10.24425/123697

Resources, P. (2008). Handbook For Mineral and Coal Exploration in British Columbia.

Sasaoka, T., Takahashi, Y., Sugeng, W., \& Hamanaka, A. (2015). Effects of Rock Mass Conditions and Blasting Standard on Fragmentation Size at Limestone Quarries. 2015(May), 331-339.

States, U., \& Mining, S. (n.d.). SMALL S E COAL MINE OPERATORS HANDBOOK. 